\title{
REPRODUKSI PEREMPUAN DALAM PERSPEKTIF ISLAM (Tinjauan terhadap Haid, Nifas, dan Istihadhah)
}

\author{
Nurdeni Dahri \\ Kanwil Kementrian Agama Provinsi Riau \\ E-mail: deniaqtor@yahoo.co.id
}

\begin{abstract}
The article explains about haidh, nifas and istihadhah according to Islamic view. Islam has a positive view on a woman who is undrgoing menstruation, nifas and istihadhah, because Islam very cares with woman reproduction health. None of the texts that consider woman who is undergoing the process of reproduction is as a dirty person and should be shunned. Likewise figh substantially negative view of women's reproductive process, although in some specific law product, figh does not reflect gender sensitivity. Real conditions of women should be the primary reference in all laws and regulations concerning menstrual problems, nifas and istihadhah. Reproductive rights of women are supposed to be guaranteed in any legal formulation. For ensure the reproductive rights of women equal to sustain human life and its descendants (hifdz annasl) which is one of the goals of Islamic Shariah (maqasid ash-shari'ah).
\end{abstract}

Kata Kunci : haid. nifas, isthihadah, teologi, figh

\section{PENDAHULUAN}

Banyak hal yang perlu diluruskan dalam hal persepsi masyarakat tentang perempuan. Terutama anggapan sadar dan bawah sadar bahwa 
kaum laki-laki lebih utama dari pada kaum prempuan. Semenjak dahulu kala, orang banyak berbicara tentang ketimpangan sosial berdasarkan jenis kelamin tetapi hasilnya belum banyak mengalami kemajuan. Persepsi itu memang sulit dihilangkan karena berakar dari atau didukung oleh ajaran teologi. Tentang hal ini Max Weber pernah menegaskan bahwa tidak mungkin mengubah perilaku masyarakat tanpa mengubah sistem etika, dan tidak mungkin mengubah etika tanpa meninjau sistem teologi dalam masyarakat.

Konsep teologi yang juga memberikan citra negatif kepada kaum perempuan ialah anggapan bahwa Hawa menjadi penyebab tergelincirnya Adam dari Sorga ke planet bumi. Karena rayuannya, Adam lengah lalu memakan buah terlarang menyebabkannya terlempar ke bumi. Akhirnya, kaum perempuan harus menanggung akibat lebih besar, seperti yang dapat dilihat dalam Kitab Talmud dan Bibel.

Dalam Agama Yahudi, asal-usul terjadinya dosa asal (original sin) juga lebih banyak mempersalahkan kaum perempuan. Bahkan kalangan misogyny menganggap perempuan sebagai "setan betina" (female demon) yang harus selalu diwaspadai. Di antara kutukan perempuan yang paling monumental ialah menstruasi/haid. Teologi menstruasi ini kemudian menyatu dengan berbagai mitos yang berkembang dari mulut ke mulut ke berbagai belahan bumi.

Teologi menstruasi dianggap berkaitan dengan pandangan kosmopolitan terhadap tubuh wanita yang sedang menstruasi. Perilaku perempuan di alam mikrokosmos diyakini mempunyai hubungan kausalitas dengan alam makrokosmos. Peristiwa-peristiwa alam seperti bencana alam, kemarau panjang dan berkembangnya hama penyebab gagalnya panen petani dihubungkan dengan adanya yang salah dalam diri perempuan

Sebagaimana diketahui, dalam hukum Islam, di samping menstruasi- ada masalah reproduksi perempuan yang terkait dengan darah yaitu nifas dan istihadhah. Tiga hal tersebut merupakan perkara penting yang harus dijelaskan dan dimengerti hukumnya. Oleh karena itu bagi perempuan wajib mengetahui tentang hukum yang berhubungan dengan ketiga darah tersebut, bahkan seorang suami tidak berhak melarang istrinya keluar rumah untuk mempelajari hukum tersebut kecuali seorang suami telah faham atau mau belajar kepada orang yang lebih pintar kemudian mengajarkan kepada istrinya.

Secara biologis, haid ${ }^{1}$ atau menstruasi merupakan siklus reproduksi yang menandai sehat dan berfungsinya organ-organ reproduksi perempuan. Menstruasi menandakan kematangan seksual 
seorang perempuan dalam arti ia mempunyai ovum yang siap dibuahi, bisa hamil, dan melahirkan anak. Dalam bahasa agama, siklus ini disebut haid.

Haid bisa menjadi salah satu pertanda bahwa seorang wanita sudah memasuki masa suburnya. Karena secara fisiologis, haid menandakan telah terbuangnya sel telur yang sudah matang. Haid merupakan bagian dari proses mempersiapkan tubuh perempuan setiap bulannya untuk kehamilan. Haid terjadi pada perempuan dewasa yang sehat dan tidak hamil. Haid adalah perubahan fisiologis dalam tubuh perempuan yang terjadi secara berkala (tiap bulan) dan dipengaruhi oleh hormon reproduksi. Periode ini penting dalam reproduksi.

Nifas ialah darah yang keluar dari rahim disebabkan kelahiran, baik bersamaan dengan kelahiran itu, sesudahnya atau sebelumnya (2 atau 3 hari) yang disertai dengan rasa sakit. Ibnu Taimiyah mengatakan: "Darah yang dilihat seorang wanita ketika mulai merasa sakit adalah nifas." Beliau tidak memberikan batasan 2 atau 3 hari, dan maksudnya adalah rasa sakit yang kemudian disertai kelahiran. Jika tidak, maka itu bukan nifas.

Dapat dipahami bahwa nifas atau darah yang keluar setelah perempuan mengalami persalinan, ia juga merupakan siklus biologis normal yang dialami perempuan. Istilah nifas itu sendiri, seperti haid, adalah bahasa agama yang diadopsi ke dalam bahasa Indonesia. Di luar kedua siklus normal ini ada satu istilah yang sering didengar yakni istihadhah. Istihadhah atau darah yang keluar di luar siklus haid dan nifas yang normal pada umumnya menandai adanya gangguan alat reproduksi.

Haid, nifas, dan istihadhah secara spesifik memperoleh perhatian dalam Islam karena di samping merupakan bagian dari perhatian Islam terhadap persoalan reproduksi perempuan juga berimplikasi terhadap banyaknya ketentuan agama mengenai perempuan, baik dalam aspek ibadah, mu'amalah, maupun munakahah. Dalam al-Qur'ân, persoalan haid tidak dibahas secara mendalam melainkan lebih ditekankan pada aspek filosofis dan teologisnya. Dalam hadits, persoalan haid, nifas, dan istihadhah sudah memasuki area yang lebih operasional. Dalam fiqh, persoalan ini, terutama istihadhah, memperoleh porsi pembahasan yang lebih detail, dan dalam batas-batas tertentu mengandung bias gender.

Tulisan berikut ini mencoba melihat persoalan haid, nifas dan istihadhah dalam perspektif Islam, yang disistematir dari al-Qur'an dan Hadis, selanjutnya dalam pandangan fiqh. 


\section{PEMBAHASAN}

\section{Haid, Nifas, dan Istihadhah dalam al-Qur'an dan Hadis}

"Haid" dalam al-Qur'an hanya disebutkan empat kali dalam dua ayat; sekali dalam bentuk fi'l mudlari (yahidl) dan tiga kali dalam bentuk ism mashdar (al-mahidl). Dari segi penamaan saja, kata haid sudah lepas dari konotasi teologis seperti agama-agama dan kepercayaan sebelumnya. ${ }^{2}$

Pandangan Islam tentang haid, sebagaimana dinyatakan oleh alQur'ân, mengandung sebuah pemikiran baru yang berbeda dengan tradisi Yahudi sebelumnya. Dalam tradisi Yahudi, perempuan yang sedang haid dianggap sebagai perempuan kotor yang bisa mendatangkan bencana sehingga harus diasingkan dari masyarakat. Selama haid ia harus tinggal dalam gubuk khusus, tidak boleh diajak makan bersama, dan bahkan tidak boleh menyentuh makanan. Tatapan mata perempuan yang sedang haid disebut mata iblis yang harus diwaspadai karena mengandung bencana. Oleh karna itu perempuan yang sedang haid harus menggunakan tanda tertentu seperti gelang, kalung, giwang, celak mata, cadar, riasan wajah yang khusus dan sebagainya agar segera dapat dikenali kalau ia sedang haid. Semua itu diberlakukan untuk mencegah "si mata Iblis"3

Pandangan teologis yang demikain negatif ini kemudian ditentang oleh al-Qur'ân dan dipertegas dalam hadits. Hal ini tampak pada sebab turunnya (asbabun nuzûl) ayat tentang haid (QS. Al-Baqarah/2:222). Diriwayatkan oleh Imam Muslim bahwa sekelompok sahabat Nabi bertanya kepada Nabi tentang perilaku orang Yahudi yang tidak mau makan bersama dan bergaul dengan istrinya di rumah ketika si istri haid. Maka turunlah ayat ini :

] r\& uqèd ö@è\% ( ÇÙ ÅsyJø9\$\# Ç’tã tRqè=t«ójo ur Ł’èdqç/t ø)s? wur ( ÇÙ ÅsyJø9\$ Îû uä!\$|jÏiY9\$\# (\#qä9Í tIôã\$\$sù ß]ø ym ô'ïB Eèdqè?ù'sù tbö EgsÜs? \#s Î*sù ( tbö ßgôüt 40́ßLym

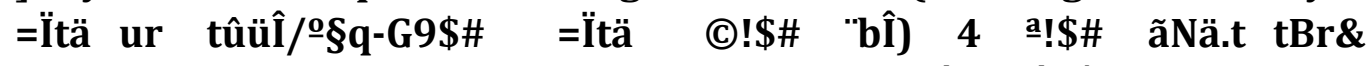
ÇËË̈̈̀̀ úïI ÎdgsÜtFßJø9\$\#

Artinya:"Mereka bertanya kepadamu tentang haid. Katakanlah (darah) haid adalah kotoran, maka menjauhlah kalian dari istri kalian di tempat keluarnya haid. Dan janganlah kalian mendekati mereka sampai mereka suci. Jika mereka telah bersuci maka datangilah (campurilah) mereka sesuai dengan cara yang diperintahkan Allah kepada kalian. Sesungguhnya Allah menyukai orang-orang yang taubat dan orang-orang yang menyucikan diri."

Selanjutnya Rasulullah SAW berkata: "Berbuatlah apa saja kecuali berhubungan seks". Mendengar ucapan Rasulullah itu kaum Yahudi 
berkomentar, "Laki-laki ini selalu ingin berbeda dengan kita". Komentar itu didengar oleh dua orang sahabat $\mathrm{Nabi}$, sehingga mereka menyampaikan hal itu kepada Nabi sambil mempertanyakan kembali apakah boleh bergaul dengan istri yang sedang haid. Mendengar kekurangyakinan sahabat itu wajah Nabi sempat berubah sehingga para sahabat mengira beliau marah. Tapi ternyata tidak. ${ }^{4}$ Demikianlah, Nabi betul-betul serius menolak tradisi kaum Yahudi yang mengisolasi perempuan haid.

Dalam ayat ini, kata "al-mahaid" disebut sebanyak dua kali. Para mufassir berbeda pendapat tentang arti kata "al-mahaid" ini. Ada yang menganggap keduanya bermakna sama yakni "haid" seperti at-Tabary. ${ }^{5}$ Namun ada pula yang membedakan makna keduanya. Kata "al-mahaid" yang pertama berarti darah haid dan kata"al-mahaid" yang kedua berarti tempat keluarnya darah haid. Abu Hayyan termasuk yang berpendapat demikian. ${ }^{6}$ Digunakannya kata "al-mahaid" dan bukan, misalnya, kata "alHaid" (perempuan yang sedang haid) memiliki implikasi teologis yang sangat dalam. Dalam kata"al-mahaid" yang pertama yakni al-Qur'ân memberikan penegasan bahwa bukan perempuan haid yang kotor melainkan darah yang keluar itulah yang kotor.

Pernyataan ini sangat berbeda dengan anggapan sebagian orang yang mengidentikkan haid dengan "perempuan yang sedang kotor". Dalam Al-Qur'ân yang dianggap kotoran adalah darahnya, dan bukan si perempuan itu sendiri. Ini adalah pernyataan yang sangat logis dan sesuai dengan kaedah umum kedokteran yang menyatakan bahwa darah haid adalah darah yang tidak diperlukan bagi organ tubuh perempuan dan harus dibuang karena jika tetap berada dalam perut justru akan membawa penyakit. Dengan argumen medis yang demikian, pernyataan Al-Qur'ân tentang haid sama sekali tidak dimaksudkan sebagai ajaran yang memandang rendah perempuan yang sedang haid.

Demikian juga dalam kata "al-mahaid" yang kedua: "fa'tazilun nisa' fil mahaid" bukan perempuan haid yang harus diasingkan dan disingkirkan melainkan para suami yang seharusnya melakukan i'tizal (tidak melakukan hubungan seksual) di tempat keluarnya darah haid (faraj/vagina) sampai perempuan tersebut suci dari haidnya. Sementara dalam selain hubungan seks perempuan harus tetap diperlakukan sebagaimana biasa.

Pandangan seperti ini lebih dikuatkan oleh hadits Nabi. Dalam banyak hadits didapatkan bahwa haid sama sekali tidak menjadi alat untuk menistakan perempuan. Melalui penuturan para istrinya, Nabi diriwayatkan melakukan apa saja terhadap istrinya yang sedang haid 
kecuali bersenggama. Nabi mandi bersama mereka dan tidur satu selimut dengan mereka. ${ }^{7}$ Hal yang sama beliau kemukakan juga untuk para sahabat laki-laki. Nabi juga menolak keras perbuatan orang-orang Yahudi yang tidak mau makan bersama dengan perempuan haid. ${ }^{8}$ Sebaliknya Nabi malah pernah minum dan menempelkan mulutnya di gelas bekas Aisyah dan menggigit daging di tempat bekas gigitan Aisyah. ${ }^{9}$ Lebih dari itu, Nabi menganjurkan perempuan yang sedang haid untuk bersamasama hadir mengikuti khutbah dan perayaan Idul Fitri dan Idul Adha. ${ }^{10}$ Perintah ini merupakan sesuatu yang tidak lazim pada saat itu; saat di mana laki-laki dan bahkan perempuan sendiri menabukan bergabungnya perempuan haid bersama masyarakat luas dalam acara-acara besar.

Perilaku Nabi menghapus batas-batas ketabuan ini mendorong para sahabat perempuan untuk berani bertanya dan membahas lebih jauh persoalan haid, nifas, dan istihadhah ini tanpa rasa malu. Dalam satu kesempatan Aisyah memuji sikap kritis perempuan Anshar yang tidak segan-segan mengungkapkan persoalan reproduksinya kepada Nabi demi tafaqquh fiddin (mendalami agama). ${ }^{11}$ Situasi dialogis seperti ini pada gilirannya mendorong banyaknya hadits yang berbicara soal haid, istihadhah, dan nifas. Dalam al-Kutub as-Sittah persoalan ini menempati satu bab khusus. Bahkan dalam Sunan Ibn Majah, masalah haid, nifas dan istihadhah ini dituangkan dalam sangat banyak halaman. Secara umum dapat dikatakan bahwa dalam hadits, spektrum pembahasan haid, nifas, dan istihadhah sudah memasuki wilayah yang lebih teknis, operasional, dan praktis.

Berkenaan dengan wacana haid, nifas dan istidhadah dalam hadits, ada satu catatan penting yang bisa dikemukakan di sini yakni hampir seluruh ketentuan tentang ketiga persoalan ini didasarkan pada dan sebagai solusi atas kasus yang terjadi pada perempuan masa itu. Hukum ditetapkan dengan mempertimbangkan kondisi perempuan.

Solusi hukum yang diberikan Nabi SAW. menyangkut perempuan yang mengalami istihadhah menjadi bukti kemauan dan kemampuan Nabi mendengar kaum perempuan. Hampir seluruh hadits tentang persoalan ini menyatakan, atau paling tidak mengindikasikan adanya dialog antara wahyu (melalui hadits Nabi) dengan perempuan sebelum turunnya suatu ketentuan. Aisyah, Ummu Salamah, Fatimah binti Abi Hubaisy, Ummu Habibah binti Jahsy, Asma binti Umais, dan Hamnah binti Jahsy, radhiyallahu anhunna - adalah sebagian nama sahabat perempuan yang berperan dalam munculnya hadits-hadits tentang haid, nifas, dan terutama istihadhah. Sebagian di antara mereka mengalami istihadhah dahsyat dan bahkan ada yang sampai menahun sehingga perlu bertanya 
kepada Nabi SAW. Menariknya, Nabi SAW. tidak memberikan jawaban yang seragam terhadap semua kasus kecuali hal-hal yang sudah pasti bisa dilakukan oleh semua perempuan seperti tetap melakukan shalat sebagaimana orang yang sedang suci serta wudhu setiap kali mau shalat. Namun untuk mandi wajib, Nabi SAW. memberikan jawaban yang berbeda-beda kepada para sahabat perempuan yang bertanya. Terhadap Ummu Habibah binti Jahsy, misalnya, Nabi SAW. memerintahkan agar mandi setiap kali mau salat wajib. ${ }^{12}$ Kepada Sahlah binti Suhail dan Asma' binti 'Umais Rasulullah memerintahkan mandi sekali untuk dua shalat wajib yakni sekali untuk dzuhur dan ashar, sekali untuk maghrib dan 'isya, serta sekali untuk subuh. ${ }^{13}$ Sedangkan terhadap Fatimah binti Abi Hubaisy Nabi malah hanya menyuruh mandi sekali saja pada saat haid biasanya berhenti. ${ }^{14}$

Ilustrasi ini menegaskan bahwa Nabi SAW. sangat mempertimbangkan kondisi perempuan sebelum memutuskan suatu hukum terhadapnya sehingga hukum yang dibuat pada akhirnya memang bisa dilaksanakan sebagaimana mestinya. Hadis-hadis tentang haid, nifas, dan istihadhah telah menunjukkan adanya dialog antara wahyu (dalam hal ini putusan Nabi SAW.) dengan orang yang menerima taklif (dalam hal ini perempuan) sehingga hukum yang terformulasikan betul-betul realistis dan sesuai dengan kemampuan penerima taklif.

\section{Haid, Nifas, dan Istihadhah dalam Perspektif Fiqh}

Masalah haid, nifas, dan istihadhah dalam fiqh memperoleh perhatian yang begitu luar biasa dari para fukaha. Banyak kitab yang khusus ditulis untuk membahas masalah ini. Diantara ulama yang menghasilkan satu jilid besar tentang masalah haid, nifas, dan istihadhah ini adalah Imam Haramain dan Abu al-Faraj ad-Darimi. Secara umum dapat dikatakan bahwa paradigma dasar fiqh tentang haid, nifas, dan istihadhah merupakan kelanjutan dari ajaran yang terdapat dalam AlQur'ân dan al-hadits. Artinya, fiqh Islam tidak memposisikan perempuan yang sedang haid, nifas dan istihadhah sebagai kelompok manusia yang kotor dan perlu diisolasi.

Fiqh memandang status mereka sama dengan orang yang sedang mengalami hadats besar (suatu kondisi yang mewajibkan seseorang untuk mandi wajib sebelum melakukan ibadah tertentu).

Dalam perspektif fiqh, hadats, baik besar maupun kecil, (suatu kondisi yang mewajibkan seseorang untuk berwudhu sebelum melakukan ibadah tertentu seperti habis kencing, buang air besar, tidur) dianggap sebagai sesuatu yang alamiah, temporer dan aksidental dan dialami oleh 
setiap manusia, sehingga hadats sama sekali bukan hal yang dipandang negatif. Dengan menempatkan haid, nifas, dan istihadhah sejajar dengan kondisi-kondisi hadats yang lain, maka fiqh sesungguhnya telah meletakkan proses reproduksi perempuan ini sebagai bagian dari kodrat perempuan yang perlu diberikan solusi hukumnya. Meskipun secara umum fiqh memandang haid, nifas dan istihadhah secara proporsional, masih ada pandangan negatif terhadap perempuan yang haid dan nifas. Dalam kitab al-Hayawan karya al-Jâhidz, misalnya, dikatakan bahwa ada empat binatang yang mengalami haid yakni perempuan, kelinci, kelelawar dan anjing hutan. ${ }^{15}$

Pernyataan ini terasa kurang memanusiakan perempuan, sebab sekalipun memang ada binatang yang mengalami menstruasi, memasukkan perempuan dalam kelompok mereka seperti mempersamakan perempuan dengan binatang. Dalam al-Hâwi terdapat keterangan bahwa haid disebut kotor karena warna darah itu jelek, baunya tidak enak, najis, dan membahayakan. ${ }^{16}$ Alasan yang dikemukakan ini menyiratkan kesan nyinyir sekaligus tidak proporsional karena tidak memuat hal yang lebih penting yakni alasan kesehatan reproduksi perempuan, seperti jika darah haid tidak dikeluarkan, ia akan menjadi kotoran yang membawa penyakit bagi perempuan. Untunglah, pendapat ini bukan merepresentasikan pendapat mayoritas ulama.

Terlepas dari cara pandang ahli fiqh mayoritas dan minoritas tersebut, ketika masuk ke belantara fiqh haid, nifas dan istihadhah lebih dalam lagi, akan didapatkan produk-produk hukum yang rumit dan bahkan sangat menyulitkan perempuan. Tanpa mengurangi penghargaan terhadap hasil ijtihad para ulama yang telah demikian serius mencurahkan perhatiannya dalam masalah ini, dapat dikatakan bahwa sebagian besar hukum tentang haid, nifas dan istihadhah sulit dikatakan membumi dan mengakomodir kemampuan perempuan untuk melaksanakan hukum tersebut. Misalnya, dalam soal pembagian perempuan istihadhah menjadi mubtadi'ah (pemula) dan mu'tâdah (sudah biasa) yang keduanya dibagi lagi menjadi mumayyizah (bisa membedakan antara darah haid dan darah istihadhah) dan ghairu mumayyizah (tidak bisa membedakan antara kedua jenis darah). Empat jenis kategori ini memiliki batasan-batasan khusus yang begitu rinci. Secara subyektif, berdasarkan pengalaman kaum perempuan, bisa dikatakan bahwa dengan batasan yang begitu rumit mulai dari mengetahui persis siklus bulanan haid, mendeteksi jenis dan warna darah, sampai hitungan waktu keluar dan berhentinya darah, amat sangat jarang perempuan yang dengan yakin bisa memastikan dirinya masuk dalam kategori yang mana. 
Padahal seluruh ketentuan tentang istihadhah dalam fiqih dibangun atas dasar paradigma mubtadi'ah - mu'tâdah dan mumayyizah - ghairu mumayyizah ${ }^{17}$ ini. Jika demikian yang terjadi, patut dipertanyakan efektifitas peraturan tersebut di lapangan, sebab sangat ironis rasanya jika sebuah formulasi hukum dibuat untuk tidak bisa dilaksanakan. Contoh lain yang bisa disebutkan adalah soal batas waktu minimal haid. Imam Syafi'i memberi batas minimal haid sehari semalam. ${ }^{18}$ Batas ini sesungguhnya tidak bermasalah jika tidak ada penjelasan yang lebih rumit dari ashhâb Syâfi'i (ulama penganut madzhab Syafi'i) yang lain.

Penjelasan itu adalah jika seorang perempuan yang haidnya tidak lancar, ia haid lebih dari satu hari tetapi ketika dirinci waktu keluarnya haid tidak sampai sehari semalam. Menurut pendapat ini, keadaan yang demikian tidak bisa dikatakan haid. Konsekuensinya ia harus meng-qadhâ seluruh shalat yang ditinggalkan. Persoalan yang muncul di sini adalah haid tidak bisa dihitung menit per menit, jam perjam, karena darah haid keluar di luar kehendak perempuan dan oleh karena itu tidak bisa dikontrol sebagaimana yang dinyatakan para fuqaha terdahulu. Ini berarti bahwa produk fiqh yang ada tidak sesuai dengan pengalaman perempuan yang dikenai hukum tersebut.

Produk hukum yang menyulitkan perempuan juga terdapat dalam ketentuan mengenai mandi wajib bagi perempuan yang sedang istihadhah (mustahâdhah). Imam Abu Hanifah, Imam Malik, dan Imam Ahmad bin Hambal mewajibkan mustahadhah mandi besar setiap kali hendak shalat wajib. ${ }^{19}$ Bisa dibayangkan betapa sulitnya ketentuan ini, terutama bagi perempuan yang tinggal di daerah yang dingin atau daerah yang kekurangan air. Begitu juga bagi perempuan yang bekerja baik di kantor, sekolah, rumah sakit, pasar, maupun tempat lainnya. Jangankan bagi perempuan yang bekerja di luar rumah, bagi perempuan yang tinggal dalam rumah saja ketentuan ini menyulitkan. Ia harus mandi sehari lima kali sambil mengurus rumah tangga, anak, suami, dan dirinya sendiri pada saat kondisi tubuhnya sedang tidak sehat. Bagi perempuan, istihadhah itu sendiri sudah merupakan problem yang cukup serius karena memperlemah fisik, menurunkan stamina, mengganggu hubungan suamiistri dan bahkan bisa mengancam nyawa kalau pendarahannya hebat.

Pada tingkat tertentu istihadhah juga menimbulkan ketakutan dan kecemasan, seperti yang dialami oleh sebagian perempuan menjelang menopouse atau perempuan yang tidak cocok dengan alat kontrasepsi tertentu. Jika demikian halnya, patut pula dipertanyakan pertimbangan kemanusiaan di balik produk hukum yang ditetapkan untuk perempuan istihadhah, yang jelas-jelas lemah secara fisik dan psikis tersebut. 
Beberapa paradoks di atas menunjukkan bahwa banyak produk fiqh yang kurang atau bahkan tidak mempertimbangkan kondisi perempuan, padahal hukum itu dirumuskan untuk mereka. Meski demikian tidak seluruh produk fiqh mengenai persoalan khusus perempuan ini seperti itu. Di sela-sela hukum yang kurang akomodatif terhadap perempuan ada pilihan produk hukum lain yang cukup akomodatif. Ini bisa ditemukan tatkala produk fiqh empat madzhab diperbandingkan dengan seksama. Sebagai contoh, masalah batas waktu minimal haid. Jika Imam Syafi'i mengatakan batas minimal haid satu hari dan Imam Abu Hanifah menyatakan tiga hari ${ }^{20}$ dengan konsekuensi sebagaimana dikemukakan di atas, maka ada fiqh Imam Malik yang menyatakan tidak ada batas minimal waktu haid. Dengan demikian setiap darah yang keluar pada masa haid -meskipun hanya sesaat- tetap disebut haid. ${ }^{21}$

Pendapat ini terasa lebih realistis untuk dijalani perempuan yang kebetulan mengalami menstruasi yang tidak lancar. Contoh lain misalnya batas minimal waktu suci di antara dua haid. Fiqh Syafi'i memang terasa memberatkan perempuan ketika dengan ketat memberi batasan suci minimal 15 hari. ${ }^{22}$ Artinya, bila masa suci belum sampai 15 hari maka darah yang keluar adalah istihadhah. Kondisi ini tentu bisa menyulitkan sebagian perempuan yang mengalami ketidakteraturan siklus haid, seperti pada sebagian gadis remaja, sebagian orang dewasa, perempuan yang mendekati masa menopause, dan perempuan yang menggunakan alat kontrasepsi tertentu. Beruntung ada pilihan fiqh lain yang lebih memahami problematika ini seperti fiqh Imam Ahmad dan Imam Ishaq yang menolak adanya batasan ini. Menurut mereka masa suci antara dua haid sesuai dengan proses alami yang terjadi. Bahkan Imam Ishaq menyatakan bahwa pembatasan 15 hari seperti itu batal. ${ }^{23}$ Formulasi hukum yang diberikan Imam Ahmad dan Imam Ishaq yang didukung oleh sebagian fukaha Malikiyah ini bisa menjadi alternatif bagi perempuan yang mengalami ketidakteraturan siklus menstruasi.

Dalam masalah mandi wajib bagi perempuan istihadhah (mustahadhah), fiqh Syafi'i, sebagaimana dikemukakan oleh An-Nawawi ahli fiqh terkemuka madzhab Syafi'i- tampak lebih akomodatif terhadap perempuan dibandingkan dengan fiqh tiga Imam besar lainnya yang mewajibkan mandi setiap waktu shalat sebagiamana dikemukakan di atas. Menurut an-Nawawi, mustahadhah hanya diwajibkan mandi besar pada saat (biasanya) haid berhenti. ${ }^{24}$ Artinya, jika mustahadhah itu biasanya menjalani haid selama tujuh hari, maka pada saat istihadhah itu ia hanya wajib mandi pada hari ketujuh dari siklus haidnya yang biasa. 
Selebihnya ia hanya wajib wudhu setiap kali masuk shalat fardhu. Solusi ini terasa logis dan realistis terutama bagi perempuan yang mengalami istihadhah dalam jangka waktu yang lama.

Sejatinya perbedaan pendapat mengarahkan untuk bersikap cermat dan teliti dalam melihat fiqh, karena fiqh memang selalu identik dengan pluralitas pendapat (ikhtilâf). Dalam pluralitas itu mesti dipilah dan dipilih mana hal yang harus terus-menerus dilakukan, sebab fiqh yang telah terumuskan itu sesungguhnya merupakan hasil ijtihâd para fukaha berdasarkan pemahaman atas teks-teks suci agama dan praktek keagamaan yang mereka ketahui. Karena ijtihâd itu sendiri berada dalam bingkai ruang dan waktu di mana sang mujtahid hidup, maka merupakan kewajaran belaka jika dalam masa dan tempat yang berbeda -seperti sekarang- diberlakukan produk hukum yang berbeda pula. Sudah saatnya fiqh yang membicarakan dan atau menyangkut masalah perempuan, melibatkan kaum perempuan dalam proses pembentukan hukumnya.

\section{SIMPULAN}

Islam, sebagaimana tergambar dalam al-Qur'ân dan al-Hadits, mempunyai pandangan yang positif terhadap perempuan yang sedang haid, nifas dan istihadhah. Tidak ada satupun teks yang menganggap perempuan yang sedang menjalani proses reproduksinya ini sebagai orang yang kotor dan harus dijauhi. Demikian juga, fiqh secara substansial tidak memandang negatif proses reproduksi perempuan ini, meskipun dalam beberapa produk hukum tertentu fiqh tidak mencerminkan sensitivitas gender.

Mengingat haid, nifas, dan istihadhah tidak hanya berkaitan dengan masalah ibadah dan hubungan suami-istri, melainkan berkaitan langsung dengan persoalan kesehatan reproduksi perempuan, maka kondisi riil perempuan sudah seharusnya menjadi acuan utama dalam seluruh produk hukum dan ketentuan yang menyangkut masalah haid, nifas dan istihadhah ini. Dewasa ini banyak variabel yang berkaitan erat dengan soal haid, nifas dan istihadhah, seperti penggunaan alat kontrasepsi, obatobatan, polusi lingkungan, tuntutan hidup yang mengharuskan perempuan mencari nafkah, dan sebagainya, yang harus dipertimbangkan dalam proses perumusan hukum tentang haid, nifas dan istihadhah. Oleh karena itu, pendekatan yang semata-mata normatif tidak cukup untuk menyelesaikan seluruh persoalan. Harus ada pendekatan interdisipliner agar hukum yang dihasilkan betul-betul menjamin perlindungan hak-hak reproduksi perempuan. 
Ilmu kedokteran mesti ikut ambil bagian dalam rumusan hukum, misalnya, tentang boleh tidaknya seorang suami berhubungan badan dengan istri yang sedang istihadhah atau habis melahirkan tapi tidak mengalami nifas, yang dalam fiqh konvensional hubungan seperti ini diperbolehkan. Hukum positif juga harus berbicara untuk memperjuangakan terjaminnya hak-hak reproduksi perempuan di lingkungan kerja, dan lingkungan sosial yang lebih luas. Demikian juga ilmu-ilmu lain yang sekiranya relevan.

Rumusan hukum dan kebijakan yang menyangkut haid, nifas dan istihadhah dan hak-hak reproduksi lainnya yang lebih luas seharusnya mengacu pada nilai moral-ideal al-Qur'ân yang dengan berani menentang praktek diskriminatif terhadap perempuan yang sedang menjalani siklus reproduksinya. Demikian juga semangat mempertimbangkan kondisi perempuan sebagaimana terdapat dalam hadits harus menjadi dasar kebijakan setiap produk hukum yang diperuntukkan bagi perempuan. Demikianlah hak-hak reproduksi perempuan memang seharusnya terjamin dalam setiap formulasi hukum. Sebab menjamin hak-hak reproduksi perempuan sama dengan menjaga kelangsungan kehidupan manusia dan keturunannya (hifdz annas) yang tidak lain merupakan salah satu tujuan syarî́ah Islam (maqâshid asy-syarî'ah).

\section{Endnotes:}

1 Secara medis, haid atau menstruasi adalah proses alami yang dialami setiap perempuan, yaitu terjadinya proses pendarahan yang disebabkan luruhnya dinding rahim sebagai akibat tidak adanya pembuahan. Proses ini umumnya terjadi pada saat perempuan memasuki usia 10-12 tahun. Proses haid diiringi dengan keadaan keluarnya darah dari kelamin keperempuanan. Dimana proses alamiah ini terjadi ratarata sekitar 2-8 hari. Darah yang keluar rata-rata $10-80 \mathrm{ml}$ per hari. Siklus haid yang normal rata-rata selama 21-35 hari. Utsaimin, Darah Kebiasaan Perempuan, (tt: tp, 1392H). h. 6

2 Diantara mitos yang berkembang adalah bahwa menstruasi merupakan kutukan bagi perempuan. Teologi menstruasi ini kemudian menyatu dengan berbagai mitos yang berkembang dari mulut ke mulut ke berbagai belahan bumi. Teologi menstruasi dianggap berkaitan dengan pandangan kosmopolitan terhadap tubuh perempuan yang sedang menstruasi. Perilaku perempuan di alam mikrokosmos diyakini mempunyai hubungan kausalitas dengan alam makrokosmos. Peristiwa-peristiwa alam seperti bencana alam, kemarau panjang dan berkembangnya hama penyebab gagalnya panen petani dihubungkan dengan adanya yang salah dalam diri perempuan. Darah menstruasi (menstrual blood) dianggap darah tabu (menstrual taboo) dan perempuan yang sedang menstruasi menurut kepercayaan agama Yahudi harus hidup dalam gubuk khusus (menstrual huts) yang dirancang untuk tempat hunian para perempuan menstruasi atau mengasingkan diri di dalam goa-goa, tidak boleh bercampur dengan keluarganya, tidak boleh berhubungan seks, dan tidak boleh menyentuh jenis masakan 
tertentu. Tatapan mata (menstrual gaze) perempuan yang sedang menstruasi yang disebut "mata iblis" (evil eye) harus diwaspadai, karena diyakini bisa menimbulkan berbagai bencana. Perempuan harus mengenakan identitas diri sebagai isyarat tanda bahaya manakala sedang menstruasi, supaya tidak terjadi pelanggaran terhadap menstrual taboo. Asal-usul penggunaan cadar atau kerudung dan berbagai macam kosmetik lainnya, menurut kalangan antropologis, berawal dari mitos menstrual taboo, yaitu untuk mencegah "si mata Iblis" dalam melakukan aksinya. Selain mengenakan cadar perempuan haid juga menggunakan cat pewarna hitam (cilla') di daerah sekitar mata guna mengurangi ketajaman pandangan matanya. Ada lagi yang menambahkan dengan memakai kalung dari bahan-bahan tertentu seperti dari logam, manik-manik, dan bahan dari tengkorak kepala manusia. Nasaruddin Umar. Jurnal Paramadina,Vol. I, th. 1998 h. 121

3 Ibid.

4 Ibnu Katsir, Tafsir Al-Qur'ân al-Adhim, (Cairo: Dar El-Turats, tth..)., Juz I, h. 248

5 Abu Hayyan, Al-Bahr al-Muhith, (Beirut : Dar el-Fikr, 1983), Juz I, h.248

6 Ibid.

7 Diantara hadis sahih yang menjelaskan hal ini, antara lain: al-Bukhari, Sahih Bukhari, Beirut:Dar Ibn Katsir al Yamamah, 1987, kitab al-Haydh bab Mubasyarah al-Haidh, hadis ke-295, 296,297, juz I, h.115. Muslim, Sahih Muslim, Beirut: Dar el-Fikr, 1992, kitab alHaydh bab Jawazu Ghasl al-Haaidh ..., hadis ke-302, juz I h. 151; bab Mubasyarah al-Haidh Fauqal Izar, hadis ke-293-294, juz I, h.149; bab al-Idhthija' ma'a al-Haidh, hadis ke-295-296, juz I h.149-150

8 Lihat Abu Dawud, Sunan Abi Dawud, Beirut:Dar el-Fikr, tth..., bab fi Mu'akalah al-Haidh wa Mujama'atuha, hadis ke-258,juz I, h.67. Lihat juga Muslim, Op.Cit., hadis ke-302.

9 Muslim, op.cit., hadis ke-300

${ }^{10}$ Ibid., Kitab al-'Idayn bab Dzikru Ibahati Khuruj an-Nisa fi'l'Idain ila al-Mushalla hadis ke890, juz I, h.389. Lihat juga al-Bukhori, Op.Cit., kitab al-Idain, bab at-Takbir Ayyam Mina ..., hadis ke- 928 dan bab Khuruj an-Nisa' wa al-Huyyadh ilal-Mushalla, hadis ke-931, juz I, h.330-331

11 al-Bukhari, op.cit., bab al-Haya' fi al-Ilm, juz I hal.60

12 Muslim, op.cit., h. 162.

${ }^{13}$ Lihat Abu Dawud, Sunan Abi Dawud, (Beirut:Dar el-Fikr, tth..)., bab fi Mu'akalah alHaidh wa Mujama'atuha, hadis ke-258

14 al-Bukhari, op.cit., bab al-Istihadhah, hadis ke-300, juz I h.117. Lihat juga Abu Dawud, Op.Cit., bab Man Qala Taghtasilumin Thuhrin ila Thuhrin, hadis ke-298, juz I h.80

${ }^{15}$ Al-Nawawi, Al-Majmu' Syarh Muhadzdzab, (Beirut : Dar el-Fikr, tth..), Jilid II, h.344

16 Ibid

17 Penggolongan perempuan istihadloh: 1) Mubtadiah Mumayyizah: yaitu belum pernah haid tetapi mampu membedakan sifat darah. Syarat-syarat membedakan darah adalah: a. Darah kuat tidak kurang dari batas minimal Haid (24 jam) ; b. Darah kuat tidak melebihi batas maksimal Haid (15 hari). c. Darah lemah tidak tidak kurang dari batas minimal suci (15 hari) jika darah terus menerus. d. Darah yang lemah harus tidak terputus oleh darah kuat. Ketentuan Hukum: Darah kuat di klasifikasikan Haid, dan yang lemah di anggap darah Mustahadloh. 2) Mubtadiah Ghoiru Mumayyizah: yaitu belum pernah haid dan tidak mampu membedakan sifat darah, termasuk kategori perempuan yang melihat darahnya denngan satu warna dan perempuan yang tidah memenuhi salah satu dari syaratnya membedakan darah. Ketentuan hukum: Yang dihukumi Haid adalah sehari semalam yang awal, dan seterusnya adalah Haid. 3) $M u ' t a d d a h$ Mumayyizah: yaitu sudah pernah Haid dan suci dan mampu membedakan sifat darah. Ketentuan hukum: darah kuat di klasifikasikan haid, dan yang lemah di anggap darah Mustahadloh, meski berbeda dengan kebiasaan masa haidnya. 4) Mu'taddah Ghoiru Mumayyizah Dzakirah Li 'Adatiha Qodron wa Waqtan: yaitu sudah 
pernah haid dan suci dan tidak mampu membedakan sifat darah tetapi ingat kebiasaan dari masa Haid dan waktunya. Ketentuan hukum: penghitungan Haid dikembalikan pada kebiasaan (adad). 5) Mu'taddah Ghoiru Mumayyizah Nasiyah Li 'Adatiha Qodron wa Waqtan: yaitu sudah pernah haid dan suci dan tidak mampu membedakan sifat darah dan lupa kebiasaan dari masa Haid dan waktunya. Ketentuan hukum: dia dihukumi haid pada sebagian hukum (bersenang-senang dengan suami antara pusar dan lutut, membaca al-Quran selain dalam Sholat, membawa dan memegang al-Quran dan berhenti dan meliwati masjid bila hawatir mengotorinya). Dan dia dihukumi suci dalam sebagian hukum (kewajiban menjalankan sholat, puasa, thowaf talak dan i'tikaf) dan dia setiap akan menjalankan sholat fardlu diharuskan mandi besar. 6. Mu'taddah Ghoiru Mumayyizah Dzakirah Li 'Adatiha Qodron La Waqtan: yaitu sudah pernah haid dan suci dan tidak mampu membedakan sifat darah tetapi ingat kebiasaan dari masa haidnya saja dan waktunya tidak ingat. Ketentuan hukum: hari yang diyakini haid di hukumi haid, dan hari yang diyaqini suci dihukumi suci, dan hari yang ada kemungkinan suci dan haid dihukumi sebagaimana orang yang lupa kebiasaan dari masa dan waktunya haid (Mutahayyiroh). 7. Mu'taddah Ghoiru Mumayyizah Dzakirah Li 'Adatiha Waqtan La Qodron: yaitu Pengertian: sudah pernah haid dan suci dan tidak mampu membedakan sifat darah tetapi ingan kebiasaan dari waktu haidnya saja dan masanya tidak ingat. Ketentuan hukum: hari yang diyakini haid di hukumi haid, dan hari yang diyakini suci dihukumi suci, dan hari yang ada kemungkinan suci dan haid dihukumi sebagaimana orang yang lupa kebiasaan dari masa dan waktunya haid.

${ }^{18} \mathrm{Ibid}, \mathrm{h} .380$

${ }^{19}$ Ibid.,h. 536

${ }^{20}$ Abu Hayyan, op.cit., h.167

${ }^{21}$ An-Nawawi, loc.cit.,

22 Ibid.

${ }^{23} \mathrm{Ibid}$.

${ }^{24}$ Ibid.h.536

\section{DAFTAR PUSTAKA}

Amin, Qasim. 1995. Sejarah Penindasan Perempuan Menggugat Islam LakiLaki, Menggurat Perempuan Baru. Penerjemah Syaiful Alam, Yogyakarta: IRCiSoD.

Bukhari. 1987. Sahih Bukhari, Beirut: Dar Ibn Katsir al Yamamah.

Carmody, Denise Lardner. 1992. Mythological Woman, Contemporary Reflections on Ancient Religious Stories. New York: Crossroad.

Dawud, Abu. tth. Sunan Abi Dawud. Beirut: Dar el-Fikr.

Hasan, Riffat. Teologi Perempuan dalam Tradisi Islam. dalam Ulumul Qur'an, Vol.1,1410

Hayyan, Abu. 1983. Al-Bahr al-Muhith. Juz. 1 Beirut : Dar el-Fikr.

Holy Bible, edisi cetakan Indonesia

Katsir, Ibnu. tth. Tafsir Al-Qur'ân al-Adhim. Juz I. Cairo: Dar El-Turats.

Madjid, Nurcholish. 1992. Islam Doktrin dan Peradaban. Jakarta: Yayasan Paramadima. 
2001. Argumen Kesetaraan Jender: Perspektif Al-Qur'an. Jakarta: Paramadina.

Mudzhar, Atho (ed.). 2001. Perempuan Dalam Masyarakat Indonesi. Yokyakarta: Sunan Kalijaga Press.

Muslim. 1992. Sahih Muslim. Beirut: Dar el-Fikr

Mustaqim, Abdul. 2003. Tafsir Feminis Versus Tafsir Patriarki: Telaah Kritis Atas Penafsiran Dekonstruktif Riffat Hasan. Yogyakarta: Sabda Persada.

Nawawi, Al-. tth. Al-Majmu' Syarh Muhadzdzab. Jilid II . Beirut: Dar el-Fikr.

Ridla', Muhammad Rasyid. 1367 H. Tafsir al-Manar, juz IV. Kairo: Dar alManar.

Shihab, Quraish. 2002. Tafsir Al-Misbah Pesan, Kesan dan Keserasian alQur'an, Vol. 9. Jakarta: Lentera Hati.

------. 2005. Perempuan, Jakarta: Lentera Hati.

Umar, Muhammad al-Razi Fakhr-u '1-Din al-'Allamah Shaba'-u '1-Din '. tth. Tafsir al-Razi, Juz 9, Beirut: Dar al-Fikr.

Umar, Nasaruddin. 1998. Jurnal Paramadina, Vol. I.

Utsaimin. 1392 H. Darah Kebiasaan Perempuan. Tp.

Walther, Wiebke. 1993. Women in Islam, from Mediaeval to Modern Time. New York: Markus Wiener Publishing Princeton.

Zamakhsyari, Al-. 1977. Al-Kassyaf 'an al-Haqaiq al-Tanzil wa 'Uyun alAqawil fi Wujuh al-Ta'wil. Bairut : Dar al-Fikr

Zuhaily, Wahbah al-. 1987. Al-Figh al-Islam wa Adillatuhu, Jilid X. Beirut: Dar al-Fikr. 